УДК $81-13$

DOI: 10.33184/YVDK-2021-04-30.39

\author{
И.В. Варуха (доц. БаиГУ, Уфа), \\ Л.А. Лузина (студент БашГУ, Уфа)
}

\title{
МЕТОД СЕМАНТИЧЕСКОГО ПОЛЯ ПРИ ИЗУЧЕНИИ ЭМОТИВОВ В НЕМЕЦКОМ ЯЗЫКЕ
}

В статье рассматривается структура семантического поля, на примере лексических единии, обозначающих страх в немеиком языке. $B$ основе исследования лежит метод семантического поля, который позволяет объединить эмотивную лексику в группу, обозначить особенности данного объединения и описать его структуру.

Ключевые слова: сема, значение, определение, семантическое поле, эмотив

The article deals with the structure of the semantic field of the lexical units denoting fear in the German language. The research is based on the method of the semantic field which enables to unite the vocabulary expressing emotions into a certain group, define the peculiarities of the unification and describe its structure.

Key words: seme, meaning, definition, semantic field, emotive unit

Словарный запас любого языка многообразен и вызывает неподдельный интерес исследователей. Однако, в силу своего аморфного характера, изучение лексики весьма затруднительно. Для изучения любого объекта необходима его четкая структуризация. Лексические единицы можно изучать, собрав их в лексико-семантические группы, так называемые лексикосемантические поля. Семантическое поле представляет собой совокупность языковых (главным образом лексических) единиц, объединенных каким-то общим (интегральным) семантическим признаком, иными словами - имеющих некоторый общий нетривиальный компонент значения [Стернин, Розенфидьд 2001: 11] и отражающих понятийное, предметное или функциональное сходство обозначаемых явлений [Кузнецов 1998: 381]. Таким 
образом метод семантического поля призван подтвердить факт системной организации лексики, демонстрируя что единство системы обеспечивается принципом интегрирования единиц предельного членения (значений слов) в более сложные единства [Чигашева 2002: 266]. Полевый способ организации языкового материала доказал свою состоятельность не только в традиционных исследованиях семантических полей, но и в относительно молодых отраслях исследовательской деятельности, таких как языковые ландшафты [Садуов 2020].

Целью данного исследования является изучение эмотивов страха, т.е. лексических единиц, которые «представляют собой экспрессивный слой языка» [Уразметова 2019: 549] и служат для обозначения данного эмоционального состояния. Следует отметить, что эмоция страх является одной из базовых эмоций человека, потому что непосредственно связана с инстинктом самосохранения [Варуха, Шамсутдинова 2019: 92]. Базовые эмоции широко представлены в словарном составе любого языка, в лексиконе немецкого языка эмоциональное состояние страха выражено большим количеством разноплановых лексических единиц, которые, безусловно, представляют интерес для исследователей лексики.

Материалом для анализа служат лексические единицы эмотивов страха. Данные единица были выделены из толковых словарей немецкого языка при помощи метода фронтального анализа. Анализируемые лексические единицы можно разбить на три основные группы, в соответствии с категориальной семой, семой частей речи. Следовательно, мы имеем группу субстантивных лексических единиц (существительные), например, die Angst, die Furcht, der Schreck, der Grusel, das Grauen, der Horror (33 наименования); группу процессуальных лексических единиц (глаголы и глагольные фразеологизмы), например, fürchten, erschrecken, schrecken einjagen, vor Furcht erstarren, ängstlich werden, schaudern vor Angst (24 наименования); группу адъективных лексических единиц (прилагательные), например, angstvoll, schreckhaft, entsetzt, erschreckt, grausig (17 наименований).

Необходимо отметить, что в основе объединения лексических единиц лежит анализ словарных дефиниций. В состав семантического поля СТРАХ в немецком языке 
включаются только те наименования, в дефинициях которых присутствует указание на эмоциональное состояние испуга [Варуха, Салимьянова 2019: 43]. Сравним словарные определения следующих прилагательных: heillos и grausig. Оба прилагательных имеют значение «ужасный», но слово heillos имеет дефиницию "gottlos, nichtswürdig, abscheulich"[11] (нечестивый, бесполезный, мерзкий), в то время как слово grausig зафиксировано в словаре как "grausen hervorrufend; grauenvoll, entsetzlich, fürchterlich"'[10] (вызывающий ужас, кошмар, испуг, страх). Таким образом, прилагательное heillos не представляет интереса для данного исследование и не включается в число лексических единиц, которые выражают эмоцию страха в немецком языке.

Для того чтобы описать особенности семантического поля эмотивов страха, основное поле делится на субполя, в зависимости от тех или иных составляющих эмоционального состояния. Для выявления данных составляющих проводится анализ словарных дефиниций и выделяются интегральная сема и дифференциальные семы. Выбор интегрального признака определяет состав и объем семантического поля, следовательно он должен соответствовать определенным требованиям [Варуха, Шамсутдинова 2020: 208]. Данный признак должен: объединять однородные лексические единицы; задавать определенную ориентацию, образуемому на его основе семантическому полю; иметь ограничительные свойства, предопределяя вхождение в состав семантического поля обозримого количества лексических единиц. Таким образом, интегральная сема, которую называют архисема, содержит общее для всех элементов семантического поля значение, максимально при этом объективное и исключающее какую-либо эмоциональную окрашенность. Для изучаемого семантического поля архисемой является словоидентификатор «страх». При дальнейшем анализе словарного толкования выделяются дифференциальные семы разного уровня, так, например, дифференциальными семами первого порядка, следовательно, основными субполями являются субполе «испытывать страх» и субполе «вызывать страх». Дальнейшее деление субполей происходит по следующим схемам. Среди лексических единиц, входящих в субполе «вызывать страх» зафиксированы наименования, выражающие степень страха 
(сильный страх), например, jemanden in Angst versetzen, jemandem Angst einjagen \{machen\}, grausig [9]. Лексические единицы, которые входят в состав субполя «испытывать страх» делятся на следующие категории:

- сильный страх: der Schreck, das Entsetzen, furcht lähmt, erschrecken.

- сопутствующая физиологическая реакция: die Panik, vor Angst vergehen, er zittert am ganzen Leibe vor Angst, habe Gänsehaut bekommen, der Schrecken ist mir durch alle Glieder gefahren, furcht blendet den Richter, vor Schreck die Sprache verlieren, Angst verbittert das Leben, die Haare stehen zu Berge, das Herz fiel ihm in die Hosen, vor Angst zittern, entsetzen lässt das Herz erstarren, versteifen, vor Angst mit den Zähnen klappern.

- склонность к страху: die Ängstlichkeit, die Furchtsamkeit, ängstlich warden.

- страх перед ситуацией: das Lampenfieber, die Todesangst, die Prüfungsangst, die Reisefieber.

Субполе «вызывать страх» представлено следующими лексическими единицами: schrecken, schrecken einjagen, einschüchtern, jemandem Angst einjagen \{machen\}, jemanden in Angst und Schrecken halten, jemanden in Angst versetzen, unheimlich, bedrohlich, grausig.

Проведенный анализ словарных дефиниций эмотивов страха в немецком языке позволяет заключить следующее. Лексико-семантическая группа объединяет лексические единицы с общим семантическим признаком, в данном конкретном случае учитывается наличие в словарной дефиниции интегральной семы «Angst (страх)». При этом дифференциальные семы, которые присутствуют в дефинициях некоторых эмотивов, позволяют исследователю выделить особенности того или иного эмоционального состояния и, следовательно, структурировать семантическое поле. Таким образом, метод семантического поля является эффективным для изучения лексического состава языка, что подтверждает продуктивность системного подхода к изучению лексики с использованием комплексных единиц.

\section{ЛИТЕРАТУРА}

1. Варуха И.В., Салимьянова Г.В. Типизация эквивалентного семантического поля «страх». - Теория и практика языковой 
коммуникации: материалы XI Международной научнометодической конференции/под редакцией Т.М.Рогожниковой; Уфимск. гос. авиац. ун-т. - Уфа: РИК УГАТУ, 2019. - С.40-45.

2. Варуха И.В., Шамсутдинова Ю.Х. Семантический анализ эмотивов страха во французском языке. - Казанская наука, 2019. - №7. - С. 92-94.

3. Варуха И.В., Шамсутдинова Ю.Х. Структура семантического поля эмотивов страха в английском языке. - Доклады Башкирского университета, 2020. - Том 5. №3. - С.207-210.

4. Кузнецов А.М. Поле. //БЭС. Языкознание. - М., 1998. - 381 с.

5. Садуов Р.Т. Культурно-языковой ландшафт г. Уфы // Коммуникативные стратегии информационного общества. Труды XII Международной научно-теоретической конференции. - СПб, 2020. - С. 129-130.

6. Стернин И.А., Розенфидьд М.Я. Слово и образ. Монография / Под. ред И.А. Стернина. - Воронеж, 2008. - 243 с.

7. Уразметова А.В. Школьные прозвища в системе номинативных средств английского языка // Доклады Башкирского университета. 2019. Том 4. №5. С. 548-553.

8. Чигашева М.А. Семантическое поле как метод изучения лексики. - Проблемы прикладной лингвистики: Сборник материалов Всероссийского семинара / Под ред. Канд. Филол. Наук А.П. Тимониной. - Пенза, 2002. - С. 266-268.

9. Deutsches Synonymwörterbuch (on-line) - URL: http://www.openthesaurus.de.

10. Duden: Deutsches Universalwörterbuch. - Mannheim, 2001.

11. Fritze M.-E., Herberg D. Synonymwörterbuch. - Leipzig, 1974. $643 \mathrm{~s}$.

(С) Варуха И.В., Лузина Л.А., 2021 г. 